\title{
Productivity, Dry Matter and Alcohol-Production Potential of Introduced Sweet Potato Clones Elsayed, A. Y. ${ }^{1}$ and A. Y. El-Khateeb ${ }^{2}$ \\ ${ }^{1}$ Vegetable Breeding Dept, Horticulture Research Institute, ARC, Egypt \\ ${ }^{2}$ Agricultural Chemistry Department, Faculty of Agriculture, Mansoura University, Mansoura, Egypt
}

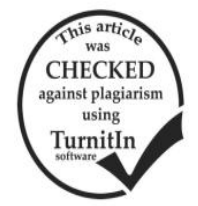

ABSTRACT

Development of new varieties with high yield and adequate biochemical traits for manufacturing industries become the main objective of sweet potato breeding programs. Currently, a limited number of sweet potato varieties are available without specific varieties for industrial purposes. The introduction of new resources is considered one of the most important approaches for genetic improvement for this crop. A total of fifteen sweet potato clones in addition to local check variety "Mabruka" were grown in a field trial during 2015 to 2016 to identify the promising clones for yield and some biochemical traits mainly related to industrial purposes and bioethanol production. High values of genetic variance combined with moderate to high heritability in broad sense for the majority of studied traits indicating the magnitude of genetic variation in the total phenotypic expression. Furthermore, high coefficient of genetic variation was found among the evaluated material for total carotenoid followed by ethanol potential with $71.61 \%$ and $37.24 \%$, respectively. Regarding genotype x season interaction, factorial analysis revealed the different responses of the tested clones for environmental conditions. The correlation coefficient analysis revealed a negative insignificant correlation between root yield and dry matter $(\mathrm{r}=-0.123)$ while positive highly significant correlation was noted between dry matter content and both total starch and ethanol production, $r=0.795$ and 0.891 , respectively. The results indicated that sweet potato promising clones have range dry matter content from $23.20 \%$ to $31 \%$; dry yield from 3.729 to 4.212 t/fed and starch from 52.91 to $65 \mathrm{~g} / 100 \mathrm{~g}$ based on dry weight. Two sweet potato promising clones, "Carriru v" and "T carro 1" have yield potential 16.09 and $13.63 \mathrm{t}$ /fed., respectively and ethanol production between 1826.3 to $2210.4 \mathrm{~L} / \mathrm{fed}$. It could be recommended that releasing these clones through the national variety release system as industrial sweet potato varieties. The clone UFVJM-56 had the highest carotenoid content with attractive orange flesh color, protein and dry matter content more than the "Mabruka" local variety that could be used as fresh type or in food industries due to its high nutritional value.

Keywords: Ipomea batatas, selection, dry weight, starch, and ethanol potential.

\section{INTRODUTION}

The sweet potato (Ipomea batatas (L) Lam) can be grown under broad range of conditions with relatively minimum agricultural inputs besides the wide adaptation of this crop to extreme environmental conditions as drought and low illness incidence that enabled it as easily cultivable and tractable crop (Cao et al. 2011; Duvernay et al. 2013). The total area of sweet potato production in Egypt estimated by 22484 feddan in 2014 with total production of about 312000 tons with average production 13.8 ton/fedden according to FAO (2016). The majority of this production comes from two main cultivars of sweet potato; Abees and Mabrouka that widely grown in the local agriculture system (Abdelmonem and Samaa, 2014).

The dry matter is the most important factor that determines the efficiency of industrial roots due to it is direct association with diverse products derived from sweet potato. For the acceptability of a new sweet potato variety, the dry matter content should be more than 25\% (Shumbusha et al. 2010). Slafer and Savin (1994) and Mwanga et al. (2007) reported high dry matter content as an important characteristic of a good sweet potato suitable for industrial that can be used for ethanol production (Loebenstein and Thottappilly, 2009; Cervantes-Flores et al. 2010). In this context, new industrial sweet potatoes breeding lines has been reported by Duvernay et al. (2013) and Ziska et al. (2009) that could produce ethanol yields of 1890-2730 L/fed compared to $1176-1590 \mathrm{~L} /$ fed for corn.

Carbohydrates represent the most component of roots in sweet potato, on dry basis it contains about 80$90 \%$ carbohydrate of which starch represent more than $60 \%$ (Woolfe, 1992). Hence, it has a higher starch yield could be produced per unit than grains (Duvernay et al.
2013; Lee et al. 2012). There are many forms of root processing as starch, alcoholic beverages, ethanol, flour and purees. The starch is used as raw material to produce glucose syrups, noodles, and organic acids, besides its importance in textile industry (Tian and Blanshard, 1991). Other processing methods include the manufacture of dried sweet potato chips, which can be milled into flour for incorporation into other food products (Woolfe, 1992).

Despite its importance, genetic improvement efforts are considered limit in sweet potato, probably due to the high levels of self-incompatibility and cross incompatibility, polyploidy with large chromosome number $(2 \mathrm{n}=6 \mathrm{X}=90)$ (Magoon et al. 1970; Ozias-Akins and Jarret, 1994). For further improvement of sweet potato, introducing of new germplasm under the local conditions is considered one of the plant breeding methods that could provide new genes such as for dry matter, total starch high protein content. In addition, introducing of dark orange-fleshed in some sweet potato varieties with high $\beta$-carotene content more than the current local varieties can be combating vitamin A deficiency (Li, 1982). Furthermore, genetic diversity studies as a pre-breeding step and the knowledge of relationships between characters could aid in the development of breeding programs in Ipomea batatas.

Developments of new varieties with high yield and adequate biochemical traits for manufacturing industries in sweet potato become the main objective of breeding programs nowadays. Currently, a limited number of sweet potato varieties, about sex, are available in Egypt without specific varieties for industrial purposes. Hence, introducing new resources of this crop is needed for genetic improvement. This work aimed to study the potential of some introduced resources of this crop for 
manufacturing applications through identify the promising resources with high dry matter, starch yield and $\beta$-carotene under the local conditions. Furthermore, evaluate the performance and magnitude of $G \times E$ interaction under the local condition of Egypt.

\section{MATERIALS AND METHODS}

Two field experiments were conducted at Elbaramon farm, Horticultural Research Station, Mansoura, Dakahlia Governorate during successive seasons 2015 and 2016. Based on root yield productivity, a set of sweet potato clones were selected from preliminary screening during summer season of 2014. Genetic materials in current study were obtained from germplasm bank University of Jequitinhonha and Mucuri, Diamantina, Brazil. Fifteen sweet potato clones (Table 1) set out in randomized complete block design with three replications in addition to local check variety "Mabrouka" for compression with a total of 48 plots of 4.5 $\mathrm{m}^{2}$. The spacing used was $1.0 \mathrm{~m}$ between lines (ridges) and $0.3 \mathrm{~m}$ between plants. Planting was done on $25^{\text {th }}$ of April in 2015 and 10 of May, 2016. Cuttings of $20 \mathrm{~cm}$ with three to four nodes were planted. All cultural practices were applied following the standard recommendations of the cultivar by Egyptian Ministry of Agriculture.

After 150 days from planting, the following traits were measured as follows: total root productivity was obtained by weighting all the roots with diameter equal or more than $2.5 \mathrm{~cm}$ for each plot and the outcome were expressed in ton/fed. Number of roots per plant was estimated as average number of roots produced by plot divided by the total number of plants. Root length and root diameter in $\mathrm{cm}$ were estimated as the average of 10 roots in each replication. The percent of dry matter content was obtained in samples of approximately $500 \mathrm{~g}$, by drying in electrical oven at $65^{\circ} \mathrm{C}$ until constant weight (Dogras et al. 1991). While the dry yield in ton/fed was estimated based on total root yield per fed. Total starch content $(\mathrm{g} / 100 \mathrm{~g}$ dry weight) was estimated according to the protocol purposed by McCleary and Monaghan (2002). Crude protein was estimated according to Kjeldahl procedure (Picha, 1985). Total carotenoid content as $\mathrm{g} / 100 \mathrm{~g}$ fresh weight was estimated according to Picha (1985). Ethanol-production potential $(\mathrm{L} / \mathrm{Fed})$ was estimated according to Lavarack (2003) based on starch content where $1 \mathrm{~g}$ starch could produce average of $0.567 \mathrm{~kg}$ ethanol, where $1 \mathrm{~kg}$ ethanol equal 1.27 $\mathrm{L}$ ethanol at $25^{\circ} \mathrm{C}$.

The data for each season were subjected to individual ANOVA according to Steel and Torrie (1960) assuming the random model effect as follows: (Yij $=\mu+G_{i}+\mathbb{E}_{j}+E_{i j}$ ) where $Y_{i j:}$ value of the ith genotype in the jth replication; $\mu$ : population means; Gi: effect of the ith genotype; Rj: effect of the jth replication; $\mathbf{E}_{\mathrm{ij}}$ : effect of experimental error. While the combined data over the two seasons were subjected to two-factor analysis of variance for obtain the effects of clones (G), (E) environments and $(\mathrm{G} \times \mathrm{E})$ interactions assuming the random model for both clones and environments. The comparison between means of the treatments was accomplished using LSD test at 5\% and 1\% levels of probability according to Snedecor and Cachran (1980). Statistical analyzes including the genetic and phenotypic parameters and simple correlation were performed with the aid of computer program GENES v.2015.5.0 (Cruz, 2013).

\section{RESULTS AND DISCUSSION}

\section{Genotype performance under the local conditions Yield components and root color}

Fifteen clones of sweet potato were tested during two summer seasons for different root yield and biochemical traits in order to identify promising clones focusing on industrial-sweet potato type. Regarding root yield (ton/fed.), significant differences at $5 \%$ and $1 \%$ of probability were observed among the evaluated sweet potato clones (Table 1). Only two clones "Cariru V" and "T carro 1" that showed higher yield than the check local variety "Mabruka" estimated by16.09 ton/fed and 13.63 ton/fed, respectively as mean over the two seasons. On the hand, during the second season, five clones gave yield more than the check variety. The mean average over two seasons demonstrated that the superiority of both "Cariru V" and "T carro 1" comparing with the check variety (Table 1).

Regarding number of roots per plant, generally, it ranged between 3-11 roots per plant as a total regardless its diameter. The clone "Arruba" gave the highest number of roots, 11 roots/plant during the first season and as mean over two years followed by "Cariru V" and "T carro 1". In general there were significant differences in number of roots between the imported clones and the check variety in each season and over the two years. Moreover, about nine clones exhibited number of roots per plant more than "Mabruka". In similar study, Ali et al.(2009), reported that maximum number of roots/plant was 5.13 .

Regarding root length in $\mathrm{cm}$, the majority of clones showed root length more than the local variety "Mabruka" especially those with cream skin and white flesh color. Similar values of root length were recorded during the two seasons with small differences. "Cariru V" recorded the highest root length of $23.83 \mathrm{~cm}$ while the clone "B. Rosa" gave the lowest average of root length, $15 \mathrm{~cm}$. The root length and root diameter estimations were only on roots of diameter equal or more than $2.5 \mathrm{~cm}$. Root diameter did not differ much from season to another for the same clone demonstrating relative stability and homogeneity regarding this trait. Broad range of variability in root diameter was observed, 2.633 to $8.217 \mathrm{~cm}$ where the clone UFVJM-30 with cream skin color and dark purple flesh color was the highest in root diameter. In similar study, Ali et al. (2009) obtained average diameter of roots estimated by $3.87 \mathrm{~cm}$. Dry matter and biochemical traits

The dry matter represents the principal factor that determines the performance of industrial roots, since it is directly related to the diverse products derived from sweet potato. The performance of sweet potato clones differed somewhat during the two seasons however the clone "T carro 1" had the highest dry matter content of $31 \%$ over the two seasons followed by "Palmas", 29.90\% compared with check variety, $22.32 \%$ with an increase of $38.85 \%$ and $33.96 \%$, respectively over the local variety "Mabruka". Similar values of dry matter content were recorded by Ayoub (2005) and Shehata et al. (2006) on sweet potato however "Mabrouka" gave higher dry matter than the 
other tested cultivars that reported by the same authors. However less values of dry matter $17 \%$ and $19 \%$ were obtained by Samy et al. (2014) for "Mabruka" than in current study.

Table 1. Mean performance of yield component traits and the predominant skin and flesh root color of introduced sweet potato clones evaluated under Egyptian conditions.

\begin{tabular}{|c|c|c|c|c|c|c|c|c|c|c|c|c|c|c|}
\hline \multirow{2}{*}{ Clones } & \multicolumn{3}{|c|}{ Root yield (ton/Fed.) } & \multicolumn{3}{|c|}{ No. of roots/plant } & \multicolumn{3}{|c|}{ Root length (cm) } & \multicolumn{3}{|c|}{ Root Diameter (cm) } & \multirow{2}{*}{$\begin{array}{l}\text { Skin } \\
\text { color }\end{array}$} & \multirow{2}{*}{$\begin{array}{l}\text { Flesh } \\
\text { color }\end{array}$} \\
\hline & $\mathbf{1}^{\text {st }} \mathrm{S}$ & $2^{\text {nd }} S$ & Mean & $1^{\text {st }} \mathrm{S}$ & $2^{\text {nd }} S$ & mean & $1^{\text {st }} \mathrm{S}$ & $2^{\text {nd }} S$ & mean & $\mathbf{1}^{\text {st }} \mathrm{S}$ & $2^{\text {nd }} S$ & mean & & \\
\hline & 786 & 8.847 & 8.817 & 1.00 & 8.667 & .833 & 19.00 & 18.00 & & & 4.933 & & $\begin{array}{l}\text { Brownish } \\
\text { orange }\end{array}$ & hite \\
\hline & 9.135 & 10.18 & 9.657 & 7.000 & 5.667 & 6.333 & 21.33 & 19.33 & 20.33 & 5.700 & 5.933 & $5.817^{\mathrm{I}}$ & $\begin{array}{l}\text { Brownish } \\
\text { orange }\end{array}$ & White \\
\hline & 10.04 & 12.49 & 11.27 & 5.000 & 6.000 & 5.500 & 22.00 & 23.67 & 22.83 & 3.633 & 4.367 & 4.000 & Cream & White \\
\hline FVIM-5 & 9.163 & 10.63 & 9.897 & 7.000 & 7.667 & 7.333 & 19.33 & 18.67 & 19.00 & 4.367 & 5.833 & 5.100 & Cream & $\begin{array}{c}\text { Dark } \\
\text { purple }\end{array}$ \\
\hline & 7.270 & 10.27 & 8.772 & 6.667 & 5.667 & 6.167 & 17.00 & 17.00 & 17.00 & & & $4.300^{\mathrm{I}}$ & $\begin{array}{c}\text { Brownish } \\
\text { orange }\end{array}$ & White \\
\hline & 8.568 & 7.560 & 8.064 & 3.667 & 3.667 & 3.667 & 17.33 & & & & & 4.933 & Cream & $\begin{array}{c}\text { Dark } \\
\text { purple }\end{array}$ \\
\hline & 17.38 & 14.80 & 16.09 & 9.000 & 6.333 & 7.667 & 24.33 & 23.33 & 23.83 & 7.700 & 7.733 & 7.717 & Cream & White \\
\hline & 9.216 & 12.71 & & 7.000 & & 6.000 & 21.67 & & & & & 8.217 & & $\begin{array}{c}\text { Dark } \\
\text { purple }\end{array}$ \\
\hline & & & & 667 & & & .33 & & & & 6.400 & 5.767 & & White \\
\hline & & & & & & & & & & & & 2.633 & $\mathrm{am}$ & White \\
\hline & & 14.76 & 13.63 & 9.000 & & 7.167 & 21.67 & 20.67 & & & 7.033 & 6.917 & Cream & White \\
\hline UFVJM-56 & 6.690 & 9.251 & 7.970 & 4.000 & 5.000 & 4.500 & 18.00 & 17.33 & 17.67 & 3.167 & 3.067 & $3.117^{\mathrm{I}}$ & $\begin{array}{r}\text { Bro } \\
\text { or }\end{array}$ & Orange \\
\hline Marmel & 9.036 & 11.62 & 10.33 & 7.333 & 8.667 & 8.000 & 20.67 & 21.00 & 20.83 & 5.500 & 6.400 & $5.950^{\mathrm{I}}$ & & White \\
\hline & & & & & & & & & & & & & & \\
\hline & & & & & & & & & & & 4.367 & & & eam \\
\hline & 12.32 & 10.67 & 11.50 & 4.667 & & 5.167 & 16.00 & 14.33 & 15.17 & 5.167 & 4.767 & 4.967 & $\begin{array}{l}\text { Dark } \\
\text { Purple }\end{array}$ & Cream \\
\hline $\mathrm{LSD}_{1 \%}^{5 \%}$ & $\begin{array}{l}285 \\
309\end{array}$ & $\begin{array}{l}2.220 \\
3.215\end{array}$ & $\begin{array}{l}2.245 \\
3.173\end{array}$ & $\begin{array}{l}.286 \\
.861\end{array}$ & $\begin{array}{l}599 \\
315\end{array}$ & $\begin{array}{l}1.429 \\
2.044\end{array}$ & $\begin{array}{l}2.349 \\
3.401\end{array}$ & $\begin{array}{l}2.413 \\
3.493\end{array}$ & $\begin{array}{l}2.345 \\
3.353\end{array}$ & $\begin{array}{l}0.859 \\
1.243\end{array}$ & $\begin{array}{l}1.276 \\
1.847\end{array}$ & $\begin{array}{l}1.071 \\
1.532\end{array}$ & ---- & --- \\
\hline
\end{tabular}

For total dry yield per unit land ton/fed, the clones "T carro 1" and "cariru v." recorded the highest dry yield per fed. estimated by 4.601 and 3.729 ton/fed, respectively with an increase $64.53 \%$ and $45.66 \%$, respectively over check variety (Table 2 ). While twelve clones produced dry yield less than the check variety. On the other hand, significant differences were observed among the tested clones including the check variety regarding the amount of total starch, $\mathrm{g} / 100 \mathrm{~g}$ in dry base. Total starch ranged from 30.85 to $65 \mathrm{~g} / 100 \mathrm{~g} \mathrm{db}$ for UFVJM-2 and B. Rosa, respectively as a mean over the two seasons. Similar values of starch content were reported by Wendy et al. (2017) on sweet potato whereas elevated values of total starch reached $74.5 \%$ were obtained by Zhang et al. (2002). However positive and highly significant correlation (0.795) was observed between dry matter content and the total amount of starch (Figure 1-b) which indicating selection for high dry matter often being associated with high starch content. While this relation was negative in the case of dry matter content with root yield $(r=-0.124)$ but statically insignificant (Figure 1-a).

For crude protein content, in general the majority of tested clones recorded higher protein content more than the check variety "Mabruka" ranged from 3.718\% to $8.025 \%$. Although the genotype UFVJM-7 recorded the highest content of protein, it had low dry matter as well as starch content beside inferior root yield than the check variety. However the clone "T carro 1" had relatively high protein content, it had high dry matter content as well as average root yield of 13.63 ton/fed.

Regarding total carotenoid which represents $\beta$ carotene the majority of its component, different clones in current study were selected basically on their skin and flesh color. As it is known, the skin as well as the flesh contains significant amounts of carotenoids and anthocyanin pigments. In general high carotenoid content was found in the clones with dark orange and dark purple flesh color. The clone UFVJM-56 recorded high carotenoid content estimated by $8.697 \mathrm{~g} / 100 \mathrm{~g}$ fresh weight. This genotype previously characterized by its medium root yielding with attractive flesh color that similar to carrot color in addition to other interest characters (Elsayed, 2014).

In general, carotenoid content varied from 0.932 to $8.697 \mathrm{~g} / 100 \mathrm{~g}$ fresh weight since the clones with cream or white flesh color showed low content of carotenoid comparing with the other clones with colored flesh (Table 1). The orange fleshed sweet potato varieties that have high $\beta$-carotene are desirable by developing countries for overcoming vitamin A deficiency and as antioxidant. In similar study of Hua et al. (2015) that found high anthocyanins content in purple sweet potato $(6.23 \mathrm{mg} / \mathrm{g} \mathrm{d} . \mathrm{w})$ while Red-fleshed and yellow-fleshed cultivars showed small amount of anthocyanins $(2.56 \mathrm{mg} / \mathrm{g}$ and $1.32 \mathrm{mg} / \mathrm{g})$, respectively while the white-fleshed cultivar showed undetectable value. 
The expected ethanol productivity, that highly depends on the amount of dry matter content as well as the available starch for fermentation process, The tested clones differed significantly in their capacity for ethanol production $\mathrm{L} /$ fed according to the amount of root yield, dry matter content, starch and other industrial factors. In current study we estimated the ethanol potential based on starch content where $1 \mathrm{~g}$ starch could produce average of $0.567 \mathrm{~kg}$ ethanol. In this context, a broad range of ethanol, $600.4 \mathrm{~L} /$ fed to $2210.4 \mathrm{~L} /$ fed was noted for UFVJM-2 and T carro 1, respectively (Table 2). In addition selection for high dry matter would be useful when screening for high ethanol sweet potato potential as result of the positive strong correlation $(\mathrm{r}=0.891)$ between dry matter content and the potential for alcohol production (Figure 1.c).

Individual and combined analysis of variance

The individual analysis of variance and mean squares of yield and biochemical traits were obtained and the results are presented in (Table 3). It appeared from the Table that the mean squares of the clones were highly significant for all studied traits in both seasons.

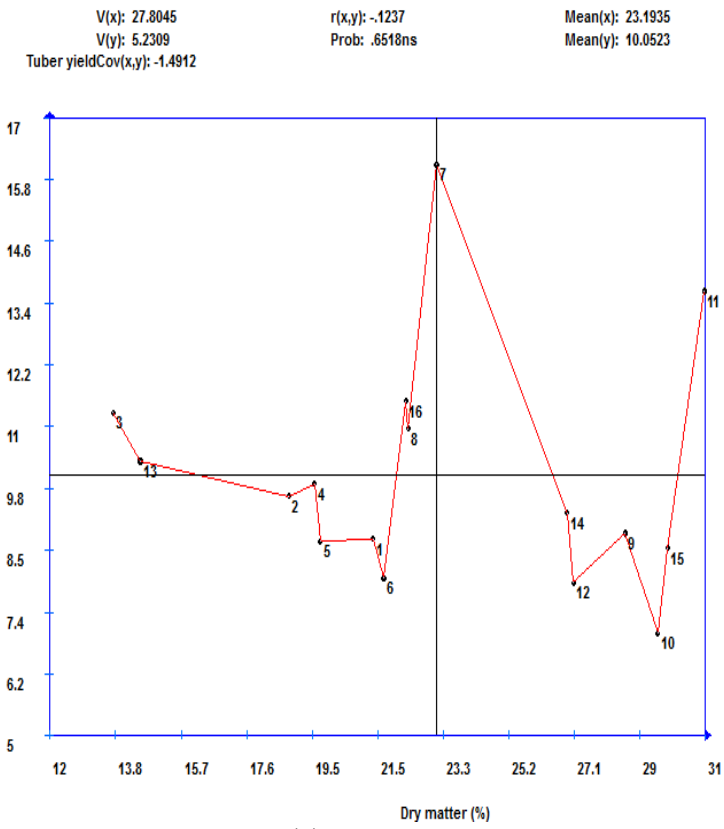

(a)
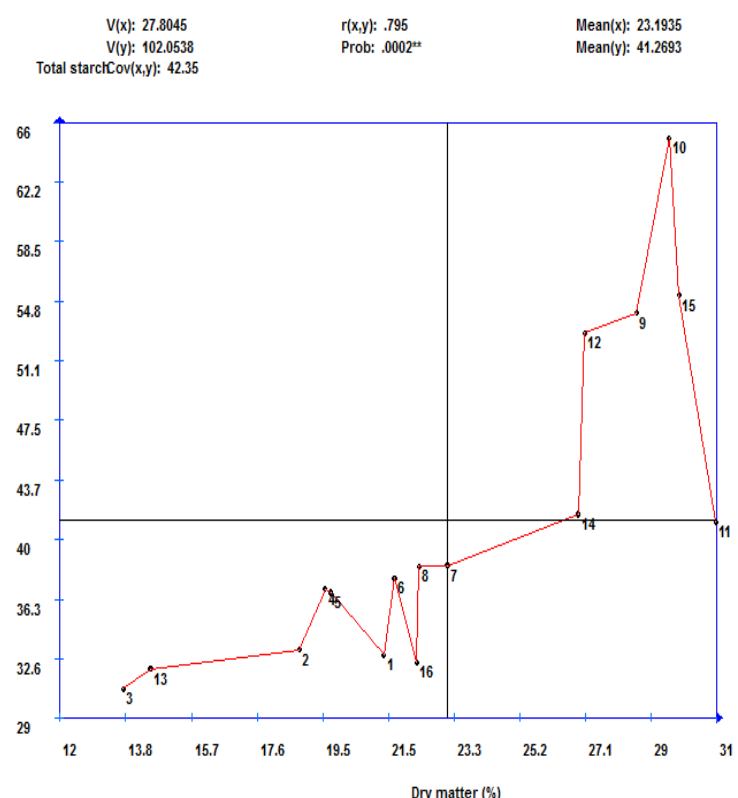

(b)
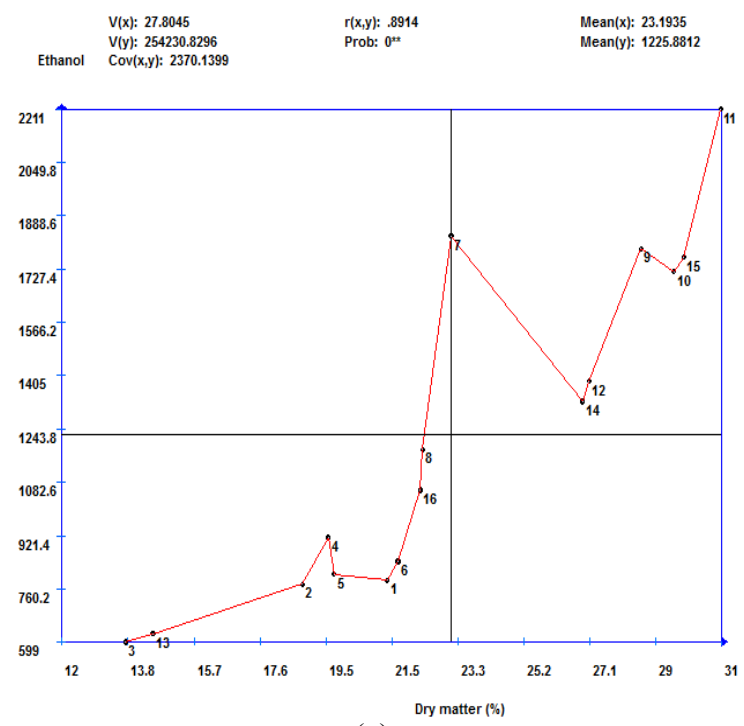

(c)

Fig. 1. The associations between dry matter content, root yield, total starch and ethanol production; Fig 1-a revealed the correlation coefficient between dry matter content $(\%)$ and root yield $(r=\mathbf{- 0 . 1 2 3})$ demonstrating the negative insignificant correlation between the both variables; Fig1-b demonstrating positive highly significant coefficient of correlation $(r=0.795)$ between root dry matter content and total starch; finally Fig 1-c explain the strong positive association $(r=0.891)$ between the potential of ethanol production and dry matter content. 
Table 2. Mean performance some biochemical traits of introduced sweet potato clones evaluated under Egyptian conditions.

\begin{tabular}{|c|c|c|c|c|c|c|c|c|c|c|}
\hline \multirow[t]{2}{*}{ Clones } & $\begin{array}{l}\text { Dry matter } \\
(\%)\end{array}$ & \multicolumn{3}{|c|}{$\begin{array}{l}\text { Dry yield } \\
\text { (ton/Fed) }\end{array}$} & $\begin{array}{l}\text { Total starch } \\
\text { (g/100gm) }\end{array}$ & $\begin{array}{c}\text { Crude Protein } \\
(\%)\end{array}$ & $\begin{array}{l}\text { Total carotenoid } \\
(\mathrm{g} / 100 \mathrm{gm} \text { fw })\end{array}$ & \multicolumn{3}{|c|}{$\begin{array}{l}\text { Ethanol } \\
\text { (L/Fed) }\end{array}$} \\
\hline & $1^{\text {st }} S 2^{\text {nd }} S$ Mean & $1^{\text {st }} S$ & $2^{\text {nd }} S$ & Mean & $1^{\text {st }} S 2^{\text {nd }} S$ mean & $1^{\text {st }} S 2^{\text {nd }} S$ mean & $1^{\text {st }} S 2^{\text {nd }} S$ mean & $1^{\text {st }} \mathrm{S}$ & $2^{\text {nd }} S$ & mean \\
\hline Arruba & $22.0020 .73 \quad 21.37$ & 1.932 & 834 & 883 & .1731 .7132 .94 & 3037.0137 .158 & $\begin{array}{llll}0.863 & 1.000 & 0.932\end{array}$ & 836.5 & 737.0 & 786.8 \\
\hline UFVJM-1 & 19.5 & 1.806 & & & & & 1.083 & 55.4 & 793.9 & 74.7 \\
\hline 2 & 14 & 1.425 & & & & & 322 & 65.3 & 635.6 & 00.4 \\
\hline & & 1.830 & & & & & & 861.9 & 968.7 & 915.3 \\
\hline & & 1.41 & & & & & & 56.0 & 953.1 & 804.5 \\
\hline & & 2.010 & & & & & & 62.5 & 725.4 & 843.9 \\
\hline V & 2 & 3.973 & & & & 0. & & 64.1 & 88 & 26.3 \\
\hline & 23 & 2.184 & & & & & & & & 81.6 \\
\hline & & 2.349 & & & & 4 & & & & 789.3 \\
\hline Rosa & .62 & 1.834 & & & & & & & 1928 & 1718.7 \\
\hline & & & & & & & & & & 10.4 \\
\hline & & & & & & & & & $11 c^{-1}$ & 1388.4 \\
\hline rmel & 13 & & & & & & & 457.6 & 792.6 & 625.1 \\
\hline Beaugard & 326.98 & 3.029 & & & & & & 1627.8 & 81025. & 1326.5 \\
\hline Palamas & $\begin{array}{lll}0 & 29.90\end{array}$ & 2.295 & & & & & & 1967.4 & 41558 & 1763.1 \\
\hline Mabruka & 21.1723 .4722 .32 & 2.608 & & & & & & 1032.7 & 71085.4 & 1059.1 \\
\hline $5 \%$ & $2.5562 .482 \quad 2.481$ & 0.505 & 0.594 & 0.549 & 4.4513. & 761.3 & $\begin{array}{llll}0.624 & 0.822 & 0.718\end{array}$ & 263.7 & 341.5 & 300.4 \\
\hline $\begin{array}{l}\text { LSD } \\
\quad 1 \% \\
\end{array}$ & 3.7013 .5943 .548 & 0.732 & 0.861 & 0.776 & 6.4454 .3965 .366 & $1.5581 .908 \quad 1.694$ & 0.9041 .1901 .027 & 381.7 & 494.5 & 429.7 \\
\hline
\end{tabular}

Table 3. The individual analysis of variance and mean squares of yield and some chemical traits of fifteen sweet potato Clones in addition to local check variety "Mabruka" under Egyptian conditions.

\begin{tabular}{|c|c|c|c|c|c|c|}
\hline \multirow{3}{*}{ Traits } & \multicolumn{6}{|c|}{ MS } \\
\hline & \multicolumn{2}{|c|}{$\begin{array}{c}\text { Replication } \\
\text { (d.f:2) }\end{array}$} & \multicolumn{2}{|c|}{$\begin{array}{l}\text { Clones } \\
\text { (d.f:15) }\end{array}$} & \multicolumn{2}{|c|}{$\begin{array}{c}\text { Error } \\
(\text { d.f:30) }\end{array}$} \\
\hline & $\mathbf{1}^{\text {st }} \mathrm{S}$ & $2^{\text {nd }} S$ & $\mathbf{1}^{\text {st }} \mathrm{S}$ & $2^{\text {nd }} S$ & $1^{\text {st }} \mathrm{S}$ & $2^{\text {nd }} S$ \\
\hline Root yield & 0.571 & 6.495 & $21.88 * *$ & $15.50 * *$ & 2.720 & 2.568 \\
\hline No. of roots/plant & 1.750 & 1.021 & $13.19 * *$ & $7.099 * *$ & 0.861 & 1.332 \\
\hline Root length & 15.90 & 4.188 & $21.06 * *$ & $21.73 * *$ & 2.874 & 3.032 \\
\hline Root Diameter & 2.766 & 6.188 & $6.998 * *$ & $7.130 * *$ & 0.384 & 0.848 \\
\hline Dry matter \% & 1.706 & 2.765 & $86.98 * *$ & $87.84 * *$ & 3.403 & 3.209 \\
\hline Dry yield & 0.155 & 0.202 & $1.900 * *$ & $1.817 * *$ & 0.133 & 0.184 \\
\hline Total starch & 28.69 & 16.90 & $486.8 * *$ & $336.6 * *$ & 10.32 & 4.802 \\
\hline Crude Protein & 1.694 & 2.007 & $7.659 * *$ & $9.172 * *$ & 0.603 & 0.905 \\
\hline Total carotenoid & 0.018 & 0.139 & $12.12 * *$ & $11.37 * *$ & 0.203 & 0.352 \\
\hline Ethanol & 125066.2 & 13234.8 & $795909.9 * *$ & $1003588 * *$ & 36206.8 & 60753.2 \\
\hline
\end{tabular}

The combined analysis over the two seasons as shown in (Table 4) summarizes the mean square of seasons, genotype $\mathrm{x}$ season interaction. For all studied traits, the effect of season was insignificant which revealed the fact that behavior of all studied traits was not changed from season to other. Regarding genotype $\mathrm{x}$ season interaction, the combined analysis of variance revealed that different levels of interaction for studied traits. In this context, root yield showed significant interaction at $5 \%$ of probability revealed the different responses of the tested clones for environmental conditions regarding its productivity. The same finding was observed for the number of roots per plant, dry matter content, total starch, crude protein and ethanol production that showed high significant $\mathrm{G} \times \mathrm{S}$ interaction at $1 \%$ of probability. While the absence of this interaction was observed for root length, root diameter and total carotenoid indicating the behavior of the different clones did not differ statically from season to another for these traits (Table 4).

Phenotypic and genetic parameters

For effective phenotypic selection, it should define its genetic value as well as the magnitude of environmental factors. This could be done by estimation of some genetic and phenotypic parameters for accurate and effective selection. Different genetic and phenotypic parameters of yield and biochemical traits were obtained and are presented in (Table 5). It appeared from the Table that the high values of genetic variance $\left(\sigma^{2} g\right)$ comparing with other variance components for all studied traits indicating the magnitude of genetic variance in the total phenotypic expression over the evaluated sweet potato clones. In addition, high values of heritability in broad sense $\left(h_{b s}^{2}\right)$ were noted for the majority of studied traits ranged from $65.52 \%$ to $98.07 \%$. While the total starch and number of roots per plant showed low coefficient of heritability.

High heritability associated with high genetic advance was obtained for dry matter \%, yield/plant (Abdelmonem and Arafa, 2014; Azevedo et al. 2015). Regarding the coefficient of genetic variation $(\mathrm{CVg})$, it permits the prediction of the genetic variability existent among the evaluated genetic materials and can be used as economic weight in some indices of selection. In this context, a broad range of $\mathrm{CVg}$ along the studied traits was obtained from $12.84 \%$ to $71.61 \%$. High coefficient of genetic variation was found among the evaluated material for total carotenoid followed by ethanol potential with $71.61 \%$ and $37.24 \%$, respectively. 
Whereas elevate coefficient of genetic variation but relatively low was detected for root length, total starch, root yield with $\mathrm{CVg}$ of $12.84 \%, 19.81 \%$ and $20.46 \%$, respectively. Regarding experimental coefficient $(\mathrm{CVe})$ as an indicator for experimental precision, moderate values of
CVe were obtained that ranged between $6.663 \%$ and $19.42 \%$ (Table 5). Furthermore, the ratio between the genetic and experimental coefficients of variation was more than 1 for all studied traits, indicating the efficacy of selection process.

Table 4. The combined analysis of variance and mean squares for yield and some chemical traits of fifteen sweet potato Clones in addition to local check variety "Mabruka" under Egyptian conditions over two seasons.

\begin{tabular}{|c|c|c|c|c|c|c|c|}
\hline \multirow[b]{2}{*}{ Traits } & \multicolumn{7}{|c|}{$\mathbf{M S}^{\dagger}$} \\
\hline & $\begin{array}{l}\text { Rep/S } \\
\text { (d.f:4) }\end{array}$ & $\begin{array}{c}\text { Rep. } \\
\text { (d.f:2) }\end{array}$ & $\begin{array}{c}\operatorname{Rep} \times S \\
(\text { d.f:2) }\end{array}$ & $\begin{array}{c}\text { Clones } \\
\text { (d.f:15) }\end{array}$ & $\begin{array}{c}\text { Seasons } \\
\text { (d.f:1) }\end{array}$ & $\begin{array}{c}\text { C. } \times \text { S. } \\
(d . f: 15)\end{array}$ & $\begin{array}{c}\text { Error } \\
\text { (d.f:60) }\end{array}$ \\
\hline Root yield & 3.533 & 1.617 & 5.449 & $31.39 * *$ & $19.82 \mathrm{~ns}$ & $5.996 *$ & 2.644 \\
\hline No. of roots/P & 1.385 & 2.698 & 0.073 & $15.49 *$ & $0.510 \mathrm{~ns}$ & $4.799 * *$ & 1.097 \\
\hline Root length & 10.04 & 16.79 & 3.292 & $39.81 * *$ & $16.67 \mathrm{~ns}$ & $2.978 \mathrm{~ns}$ & 2.953 \\
\hline Root Diameter & 4.477 & 8.613 & 0.341 & $13.75 * *$ & $2.734 \mathrm{~ns}$ & $0.381 \mathrm{~ns}$ & 0.616 \\
\hline Dry matter \% & 2.235 & 4.160 & 0.311 & $166.8 * *$ & $2.208 \mathrm{~ns}$ & $7.997 * *$ & 3.306 \\
\hline Dry yield & 0.178 & 0.018 & 0.339 & $3.348 * *$ & $0.767 \mathrm{~ns}$ & $0.369 *$ & 0.158 \\
\hline Total starch & 22.79 & 43.69 & 1.902 & $612.3 *$ & $54.74 \mathrm{~ns}$ & $211.1 * *$ & 7.562 \\
\hline Crude Protein & 1.850 & 3.226 & 0.474 & $14.39 * *$ & $1.249 \mathrm{~ns}$ & $2.438 * *$ & 0.754 \\
\hline Total carotenoid & 0.078 & 0.030 & 0.127 & $23.05 * *$ & $0.008 \mathrm{~ns}$ & $0.444 \mathrm{~ns}$ & 0.277 \\
\hline Ethanol & 69150.5 & 28764.4 & 109536.6 & $1525279.0 * *$ & 113671.4 & $274218.9 * *$ & 48480.0 \\
\hline
\end{tabular}

$\uparrow$ Degree of freedom was calculated assuming the random effect of both clones and seasons under the current investigation.

Table 5. Estimation of genetic variance $\left(\sigma^{2} g\right)$, genetic-environment interaction variance $\left(\sigma^{2} g z s\right)$, residual variance $\left(\sigma^{2} e\right)$, broad sense heritability $\left(\mathrm{h}^{2}\right)$, coefficients of genetic variation $\left(\mathrm{CV}_{\mathrm{g}}\right)$ and environmental variation $\left(\mathrm{CV}_{\mathrm{e}}\right)$ for yield and some biochemical traits in sweet potato introduced under local conditions.

\begin{tabular}{|c|c|c|c|c|c|c|c|c|c|c|}
\hline P. & Root yield & $\begin{array}{c}\text { No. of } \\
\text { roots/plant }\end{array}$ & $\begin{array}{c}\text { Root } \\
\text { length }\end{array}$ & $\begin{array}{c}\text { Root } \\
\text { Diameter }\end{array}$ & $\begin{array}{c}\text { Dry } \\
\text { matter }\end{array}$ & $\begin{array}{c}\text { Dry } \\
\text { yield }\end{array}$ & $\begin{array}{r}\text { Total } \\
\text { starch }\end{array}$ & $\begin{array}{c}\text { Crude } \\
\text { Protein }\end{array}$ & $\begin{array}{c}\text { Total } \\
\text { carotenoid }\end{array}$ & Ethanol \\
\hline$\sigma^{2} g$ & 4.232 & 1.782 & 6.139 & 2.228 & 26.47 & 0.496 & 66.87 & 1.992 & 3.768 & 208510.0 \\
\hline$\sigma^{2} g x s$ & 1.117 & 1.234 & 0.008 & -0.079 & 1.564 & 0.070 & 67.85 & 0.561 & 0.056 & 75246.3 \\
\hline$\sigma^{2} e$ & 2.644 & 1.097 & 2.953 & 0.616 & 3.306 & 0.159 & 7.562 & 0.754 & 0.277 & 48480.0 \\
\hline$h_{b s}^{2} \%$ & 80.89 & 69.02 & 92.52 & 97.23 & 95.21 & 88.95 & 65.52 & 83.06 & 98.07 & 82.02 \\
\hline $\mathrm{CVg} \%$ & 20.46 & 21.18 & 12.84 & 28.72 & 22.18 & 30.45 & 19.81 & 22.80 & 71.61 & 37.24 \\
\hline CVe \% & 16.17 & 16.61 & 8.907 & 15.10 & 7.839 & 17.22 & 6.663 & 14.02 & 19.42 & 17.96 \\
\hline $\mathrm{CVg} / \mathrm{CVe}$ & 1.265 & 1.275 & 1.441 & 1.901 & 2.829 & 1.768 & 2.973 & 1.625 & 3.686 & 2.073 \\
\hline
\end{tabular}

In current study, a set of sweet potato clones were tested for yield and biochemical properties related to industrial use. The clones varied in the total root yield, number of roots per plant, root diameter, length, dry matter content and starch content. The accumulation of dry matter which is a measure of whole-plant photoassimilation varied greatly along the studied clones. White and cream fleshed sweet potato has the potential of starch content and ethanol yield higher than the other fleshed sweet potato colors. The cream skin and white flesh color of "Cariru v" had the highest significant root yield and dry weight per fed however its moderate starch content, this genotype is a promising for ethanol production per unit $(1826.3 \mathrm{~L} / \mathrm{fed})$. While "T carro 1 " gave the highest dry matter, 4.212 ton/fed, with the highest ethanol production, $2210.4 \mathrm{~L} / \mathrm{fed}$, that could be recommended for bio-ethanol production in further studies. On the other hand, UFVJM-56 had the highest carotenoid content with attractive orange flesh color, protein and dry matter content more than the "Mabruka" local variety. Such characters of UFVJM-56, could be used in direct consumption as well as for industrial use due to its high nutritional value. For well explore the high GxE interactions, further adaptation studies with different locations should be conducted to determine which clones are more acceptableand yield stable.

\section{REFERENCES}

Abdelmonem S.A. El Gendy and Samaa-Abd Khalik, Arfa (2014). Improving local varieties of sweet potato by simple recurrent selection. Middle East Journal of Agriculture Research, 3(3): 511-516.

Ali, M. R.; D. J. Costa; M. J. Abedin; M. A. Sayed and N. C. Basak (2009). Effect of fertilizer and variety on the yield of sweet potato Bangladesh J. Agri. Res. 34(3):473-480.

Ayoub, I. I., (2005) Effect of fertigation and plant population on growth, yield and storability of sweet potato grown under sandy soil conditions. Ph.D. Thesis, Fac. Agric., Zagazig Univ., Egypt.

Azevedo AM; Andrade Júnior VC; Fernandes JSC; Pedrosa $\mathrm{CE}$ and Oliveira CM. (2015). Agronomic performance and genetic parameters of sweet potato genotypes.. Horticultura Brasileira 33: 084-090.

Cao Y.; Tian H.; Yao K. and Yuan Y (2011) Simultaneous saccharification and fermentation of sweet potato powder for the production of ethanol under conditions of very high gravity. Front Chem Sci Eng 5(3):318-324.

Cervantes-Flores J; Sosinski B; Pecota K; Mwanga ROM; Catignani G; Truong V; Watkins R; Ulmer $\mathrm{M}$ and Yencho $G$ (2010) Identification of quantitative trait loci for dry matter, starch and $\beta$-carotene content in sweetpotato. Mol Breeding. 5: 1-16

Cruz, C.D. (2013) GENES- a software package for analysis in experimental statistics and quantitative genetics. Acta Scientiarum. v.35, n.3, p.271-276. 
Dogras, C.; Simons, A. and C. Psomakelis, (1991) Sugar and dry matter changes in potatoes stored in a clamp in a mountainous region of Northern Greece. Potato Research 34:211-214

Duvernay WH; Chinn MS and Yencho GC (2013) Hydrolysis and fermentation of sweet potatoes for production of fermentable sugars and ethanol. Ind Crop Prod 42:527-537.

Elsayed, A.Y (2014) Genetic diversity of sweet potato revealed by descriptors multicategorical binaries. Journal of Agricultural Chemistry and Biotechnology, V. 5 No. (2): 87-100.

FAOSTAT, 2016. Food and Agriculture Organization of the United Nations, Rome, Italy. http:// faostat. fao.org/ site/567/ default. aspx\#ancor

Hua Ji1; Haixin Zhang; Hongtao Li and Yunchao Li (2015) Analysis on the Nutrition Composition and Antioxidant Activity of Different Types of Sweet Potato Cultivars. Food and Nutrition Sciences, 2015, 6, 161-167.

Jindal, S.K.; D. Arora and T.R. Ghai, (2010). Variability studies for yield and its contributing traits in okra. Electronic Journal of Plant Breeding, 1/6: 14951499.

Lavarack BP. (2003) Estimates of ethanol production from sugar cane feedstocks. In: Hogarth DM, editor. Proceedings-Conference of the Australian Society of Sugar Cane Technologists held at Townsville, Queensland, Australia, 6-9, pp: 69.

Lee W-S; Chen I-C; Chang C-H and Yang S-S (2012) Bioethanol production from sweet potato by coimmobilization of saccharolytic molds and Saccharomyces cerevisiae. Renew Energy 39:216222

Li, L. (1982) Breeding for increased protein content in sweet potatoes. In R.L. Villareal and T.D. Griggs (eds.), In Sweet Potato, Proceedings of the First International Symposium AVRDC, Tainan, Taiwan: AVRDC, pp. 345-354.

Loebenstein G and Thottappilly G (2009) The sweet potato. Springer Verlag, Dordrecht.

Magoon, M.L.; R. Krishnan and K.V. Bai (1970) Cytological evidence in the origin of sweet potato. Theor. Appl. Gene. 40: 360-366.

McCleary, B.V. and Monaghan, D.A (2002) Measurement of resistant starch. Journal of AOAC International V. 85, Issue 3, P:665-675

Mwanga Z,; Mataa M and Msabaha M (2007) Quality and yield stability of orange fleshed sweet potato (Ipomoea batatas) varieties grown in different agroecologies. Afr Crop Sci J 8: 339-345
Ozias-Akins, P. and R.L. Jarret. (1994) Nuclear DNA content and ploidy levels in the genus Ipomoea. J. Am. Soc. Hort. Sci.119: 110-115.

Picha, D.H. (1985). Crude protein, minerals, and total carotenoid in sweet potatoes. J. Food Sci. 50: 17681769.

Samy, M.M., Mervat G. Abd El-Aziz and Nagwa A. Mohamed (2014) Effect of some Agricultural Treatments on some Sweet Potato Cultivars Middle East Journal of Agriculture Research, 3(4): 12211231.

Shehata, S. A.; A. Abou El-Yazied and M. M. El-Mogy (2006). Effect of fertilization and irrigation on yield and quality of sweet potato. Annals of Agric. Sci. Moshtohor, 44(4): 1707-1724.

Shumbusha D; Tusiime G; Edema R; Gibson P and Mwanga ROM (2010) Diallel analysis of root dry matter content in sweetpotato, in: Ruforum (ed) Second Ruforum Biennial Meeting Ruform, Entebbe, Uganda, p 1013

Slafer GA and Savin R (1994) Source sink relationships and grain mass at different positions within the spike in wheat. Field Crops Res. 37: 39-49

Snedecor, G.W. and W.G. Cochran, (1980) Statistical methods. 7th Ed. Iowa State Univ. Press Ames. Iowa, USA.

Steel, R.G. and J.H. Torrie (1960) Principles and procedures of statistics. Mc-Graw Hill Book Company, INC. New York.

Tian, J. E. Rickard and J. M. V. (1991) Blanshard, "Physicochemical Properties of Sweet potato Starch," Journal of the Science of Food and Agriculture, Vol. 57, No. 4, pp. 459-491.

Wendy A. Mussolinea; Janice R. Bohacb; Brian J. Bomanc; Sabrina Trupia and Ann C. Wilkie (2017) Agronomic productivity, bioethanol potential and postharvest storability of an industrial sweet potato cultivar. Industrial Crops and Products, v 95, P: 96103

Woolfe, J.A., (1992) Sweet potato: An untapped food resource. Cambridge University Press, Cambridge, UK.

Zhang, Z.; C. C. Wheatley and H. Corke (2002) Biochemical changes during storage of sweet potato roots differing in dry matter content. Postharvest Biol. Technol. 24:317-325.

Ziska LH; Runion GB; Tomecek M; Prior SA; Torbet HA and Sicher R (2009) An evaluation of cassava, sweet potato and field corn as potential carbohydrate sources for bioethanol production in Alabama and Maryland. Biomass Bioenergy 33(11):1503-1508.

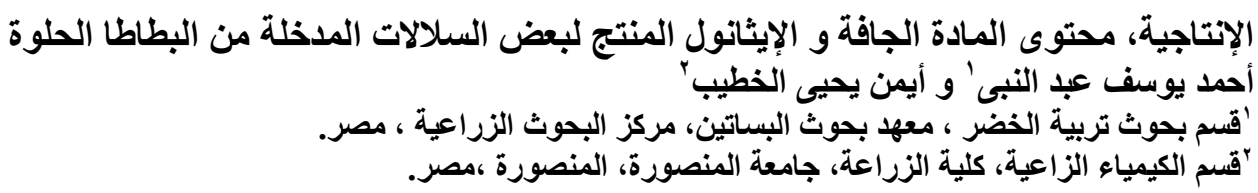

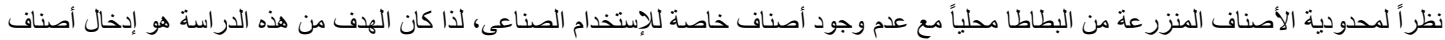

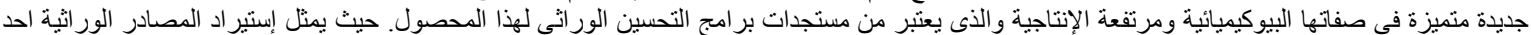

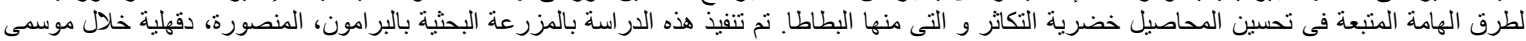

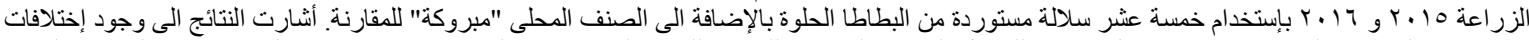

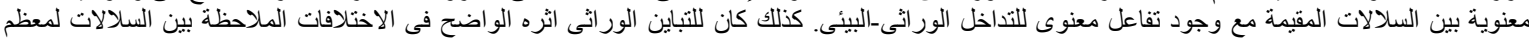

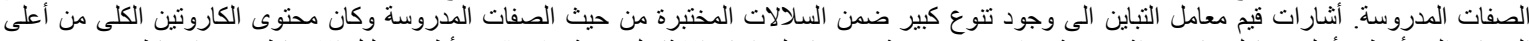

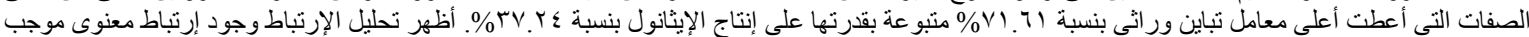

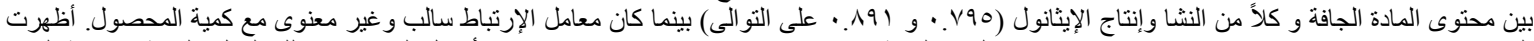

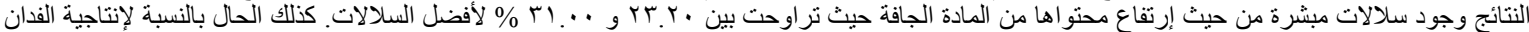

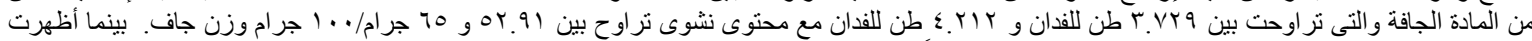

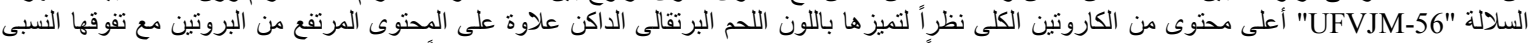

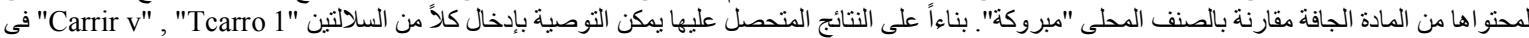

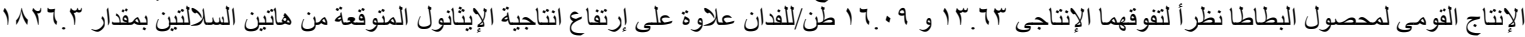

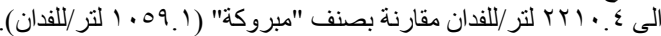

